\title{
Erratum to: Procedures and recommended times in the care process of the patient with pancreatic cancer: PAN-TIME consensus between scientific societies
}

\author{
R. Vera ${ }^{1}$ - A. Ferrández ${ }^{2}$ C. J. Ferrer ${ }^{3}$ C. Flores $^{4}$ - C. Joaquín ${ }^{5}$ • \\ S. López ${ }^{6}$ T. Martín ${ }^{7}$ E. Martín $^{8} \cdot$ M. Marzo ${ }^{9}$ A. Sarrión ${ }^{10}$ - E. Vaquero ${ }^{11}$. \\ A. Zapatero ${ }^{12} \cdot$ J. Aparicio ${ }^{1}$
}

Published online: 15 March 2017

(c) The Author(s) 2017. This article is an open access publication

\section{Erratum to: Clin Transl Oncol DOI 10.1007/s12094-016-1609-7}

The article Procedures and recommended times in the care process of the patient with pancreatic cancer: PAN-TIME consensus between scientific societies, written by R. Vera, A. Ferrández, C. J. Ferrer, C. Flores, C. Joaquín, S. López, T. Martín, E. Martín, M. Marzo, A. Sarrión, E. Vaquero, A. Zapatero, J. Aparicio, was originally published

The original article was corrected.

The online version of the original article can be found under doi:10.1007/s12094-016-1609-7.

\section{R. Vera}

ruth.vera.garcia@cfnavarra.es

Spanish Society of Medical Oncology, Madrid, Spain

2 Spanish Society of Pathological Anatomy, Madrid, Spain

3 Spanish Society of Radiation Oncology, Madrid, Spain

4 Spanish Society of General and Family Physicians, Madrid, Spain

5 Spanish Society of Endocrinology and Nutrition, Madrid, Spain

6 Spanish Society of Surgical Oncology, Madrid, Spain

7 Spanish Society of Medical Radiology/Spanish Society of Abdominal Radiology, Madrid, Spain

8 Spanish Association of Surgeons, Madrid, Spain

9 Spanish Society of Family and Community Medicine, Madrid, Spain

10 Spanish Society of Primary Care Physicians, Madrid, Spain

11 Spanish Association of Gastroenterology, Madrid, Spain

12 Spanish Society of Internal Medicine, Madrid, Spain electronically on the publisher's internet portal (currently SpringerLink) on 19 January 2017 without open access.

With the author(s)' decision to opt for Open Choice the copyright of the article changed on 15 March to (c) The Author(s) 2017 and the article is forthwith distributed under the terms of the Creative Commons Attribution 4.0 International License (http://creativecommons.org/licen ses/by/4.0/), which permits use, duplication, adaptation, distribution and reproduction in any medium or format, as long as you give appropriate credit to the original author(s) and the source, provide a link to the Creative Commons license and indicate if changes were made.

Funding Celgene and Baxalta (now Shire) have supported this consensus. However, they have not participated in its development, analysis, interpretation, or writing.

Open Access This article is distributed under the terms of the Creative Commons Attribution 4.0 International License (http://crea tivecommons.org/licenses/by/4.0/), which permits use, duplication, adaptation, distribution and reproduction in any medium or format, as long as you give appropriate credit to the original author(s) and the source, provide a link to the Creative Commons license and indicate if changes were made. 